\title{
BARBARA KUBIAK
}

Politechnika Białostocka

b.kubiak@pb.edu.pl

\section{Ludwik Grzebień SJ, Organizacja bibliotek jezu- ickich w Polsce od XVI do XVIII wieku, Kraków 2013, 250 stron}

Prawie po 40 latach od pierwszego wydania nakładem Wydawnictwa WAM Akademia Ignatianum w Krakowie ukazało się drugie wydanie niezmiernie ciekawej pracy dotyczącej bibliotek jezuickich w Polsce. Autorem pracy jest prof. Ludwik Grzebień SJ, członek Towarzystwa Jezusowego (SJ) od 1956 r., teolog, historyk, filozof. Autor około 750 prac dotyczących głównie historii zakonu jezuitów. Pierwsze wydanie Organizacja bibliotek jezuickich w Polsce od XVI do XVIII wieku cieszyło się dużą poczytnością wśród historyków bibliotekarstwa, jednakże ze względu na sposób wydania było trudno dostępne. Nowe wydanie jest dostępne i jednocześnie uzupełnione o znacznie rozszerzoną bazę źródłową.

Towarzystwo Jezusowe (Societas Jesu, SI) - jezuici - męski papieski zakon apostolski Kościoła katolickiego zatwierdzony przez papieża Pawła III w 1540 r., zostało założone w głównej mierze do walki z reformacją, by bronić i rozszerzać wiarę oraz naukę Kościoła katolickiego, przede wszystkim przez publiczne nauczanie. Od początku istnienia zakonu podstawowymi zadaniami odróżniającymi jezuitów od innych zakonów było m.in. stałe edukowanie własnych członków - tak aby posiadali oni możliwie jak najpełniejsze wykształcenie, by móc rozumieć otaczającą rzeczywistość. Można to było osiągnąć tylko poprzez rozwój szkolnictwa. Jezuici w niektórych państwach Europy (np. w Hiszpanii, we Włoszech, w Polsce) przyczynili się do stworzenia podstaw systemu szkolnictwa podstawowego i średniego. Szkolnictwo oczywiście nie mogło się rozwijać bez książek, bez dobrze funkcjonującej biblioteki. Powstawały więc biblioteki. Organizacja bibliotek jezuickich w XVI w. stała się w okresie odrodzenia wzorem do urządzania wszystkich bibliotek europejskich i w swym zrębie przetrwała do czasów dzisiejszych.

Z pracy prof. Grzebienia uzyskujemy szczegółowe informacje dotyczące organizacji bibliotek jezuickich w Polsce. Liczne prace historyczne poświę- 
cone zakonowi jezuitów pomijały biblioteki i ich księgozbiory. Stało się to dlatego, gdyż po kasacji zakonu w 1773 r. zaginęła większość archiwaliów jezuickich.

Celem pracy jest pokazanie przeszłości księgozbiorów jezuickich tak, aby zrozumieć organizację życia zakonnego oraz rolę i zadania biblioteki w różnych placówkach zakonnych.

Całość pracy podzielono na cztery zasadnicze kwestie mówiące o organizacji zakonu, gromadzeniu zbiorów, przechowywaniu i porządkowaniu oraz o udostępnianiu.

Czasowo praca obejmuje okres przedkasacyjny Towarzystwa Jezusowego, tj. lata 1564-1773. Terenowo zaś - całość asystencji polskiego zakonu, czyli 4 prowincje: wielkopolską, małopolską, litewską i mazowiecką, które leżały w granicach przedrozbiorowego państwa polskiego lub należały do zasięgu jezuitów polskich jak Ryga, Dorpat, Smoleńsk.

Głównymi źródłami dla poznania przeszłości bibliotek jezuickich są: katalogi biblioteczne, które zachowały się dla niektórych placówek zakonnych, kroniki domów zakonnych lub diariusze, sprawozdania ze stanu kolegiów w okresie rządów każdorazowego rektora, księgi rachunkowe, gdzie znajdujemy informacje o zakupach nowych pozycji, nekrologi i żywoty zmarłych jezuitów polskich, plany kolegiów jezuickich informujące o lokalizacji bibliotek, Raport Komisji Rozdawniczej, Sprawozdania Komisji Edukacyjnej, gdzie po kasacji zakonu zostały opisane księgozbiory, korespondencje, zachowane egzemplarze książek z bibliotek jezuickich, z których można było m.in. poznać exlibrisy, rozporządzenia skierowane do polskich jezuitów na temat zakonnych księgozbiorów.

Wiek XVI był w Polsce stuleciem największego rozwoju księgozbiorów kościelnych i świeckich. W tym czasie jezuici zadomowili się w kilku większych miastach Polski, otwierając szkoły, a przy nich biblioteki. Zajęcia szkolne, walka z reformacją, praca pisarska wymagały odpowiednich księgozbiorów i dlatego zakon bardzo szybko wypracował swoje ustawodawstwo w zakresie bibliotek. W pierwszym okresie pobytu jezuitów na ziemiach polskich księgozbiory ich rosły szybko, były też dobrze uporządkowane. Ale już w 1621 r. rozpoczął się dla bibliotek jezuickich okres najcięższy. Wojny, grabieże, zniszczenia, pożary dziesiątkowały księgozbiory. Dopiero w latach 80. XVII w. zadbano o poprawę sytuacji bibliotek w kolegiach jezuickich. W okresie baroku pomyślano nie tylko o samych księgozbiorach, ale i pomieszczeniach bibliotecznych, które stały się najbardziej reprezentacyjnymi lokalami w kolegiach. Oświecenie przyniosło odrodzenie bibliotek. Księgozbiory powiększano licznymi zakupami książek polskich i zagranicz- 
nych. Rozumiano powiązanie bibliotek z rozwojem oświaty. Finał bibliotek jezuickich był w większości tragiczny. Rok 1773, data kasacji zakonu, położył kres prawie wszystkim księgozbiorom Towarzystwa. Dzisiaj po przeszło dwóch wiekach nie istnieje już ani jedna biblioteka jezuicka, która posiadałaby większość dawnych pozycji. Trzeba pamiętać, że księgozbiory jezuickie w Polsce nie odbiegały od księgozbiorów w innych krajach Europy, a $\mathrm{w}$ porównaniu $\mathrm{z}$ innymi bibliotekami zakonnymi stały na nieco wyższym poziomie. Biblioteki jezuickie odegrały kulturową rolę dla podtrzymania języka i ducha narodowego Polaków. Do dzisiaj książki z dawnych zbiorów jezuickich stanowią znaczną część starodruków w bibliotekach, stanowiąc warsztat do badań nad kulturą i historią Polski. Przepisy dla bibliotek jezuickich nie straciły wiele ze swej aktualności. Zasługi jezuitów dla nauki, kultury i bibliotekoznawstwa są niekwestionowane.

Książka Ludwika Grzebienia SJ, Organizacja bibliotek jezuickich w Polsce od XVI do XVIII wieku, jest pracą wybitną, z którą powinni się zapoznać nie tylko bibliotekarze i historycy. 